\title{
Larval therapy from the patient's perspective
}

\section{Terapia larval sob a ótica do paciente}

\section{Terapia larval bajo la óptica del paciente}

\author{
Simone Maria da Silva ${ }^{1}$, Rejane Medeiros Millions², Rita de Cássia Almeida³, João Evangelista da Costa4, *
}

\section{ORCID IDs}

Silva SM (D) https://orcid.org/0000-0002-2290-5332

Millions RM (D) https://orcid.org/0000-0001-9541-6516

Almeida RC (iD https://orcid.org/0000-0002-1109-4888

Costa JE (D) https://orcid.org/0000-0003-2257-3611

\section{HOW TO CITE}

Silva SM; Millions RM; Almeida RC; Costa JE. Larval therapy from the patient's perspective. ESTIMA, Braz. J. Enterostomal Ther., 2020, 18: e3020. https://doi.org/10.30886/estima.v18.963_IN

\begin{abstract}
Objective: to describe the perception of the patient undergoing larval therapy. Method: qualitative, exploratory-descriptive study, using oral history as a data collection technique and methodological framework, in the form of oral life history. Six patients with difficult-to-heal wounds participated in the study, followed by the dressing committee of a teaching hospital in Natal, Rio Grande do Norte, undergoing larval therapy. Results: the testimonies of the patients/collaborators point to various values, such as belief, fear, acceptance, improvement of the wound and pain. They revealed that there is no major objection and that clarification regarding the treatment instituted proved to be important in the acceptance decision. Conclusion: the feelings expressed by the patients, such as improvement of the wound, reduction of pain and odor, optimization of the healing process, emergence of sparks of hope regarding the return to their life, among others, translate the benefits of Larval Therapy (LT). Despite the seizure caused by the animal's movement over the affected area and the disgust it causes to some professionals and people, LT was considered wonderful, especially for its effectiveness in cleaning the wound without the need for new invasive procedures such as cutting and surgical debridement.
\end{abstract}

DESCRIPTORS: Patient-centered care; Wound healing; Biological therapy; Stomatherapy.

\footnotetext{
1. Empresa Brasileira de Serviços Hospitalares - Ambulatório de Dermatologia - Setor de Curativo - Natal (RN), Brazil,

2. Escola Superior de Enfermagem do Porto - Porto, Portugal.

3. Universidade do Porto - Porto, Portugal.

4. Universidade Federal do Rio Grande do Norte - Hospital Universitário Onofre Lopes - Natal (RN), Brazil.

*Correspondence author: dacostajoaoevangelista@gmail.com

Received: Oct. 13, 2020 | Accepted: Nov. 26, 2020
} 


\section{RESUMO}

Objetivo: descrever a percepção do paciente submetido à terapia larval. Método: estudo qualitativo, exploratório-descritivo, tendo como técnica de coleta de dados e referencial metodológico a historia oral, na modalidade da história oral de vida. Participaram do estudo seis pacientes com feridas de difícil cicatrização, acompanhados pela comissão de curativos de um hospital escola em Natal, Rio Grande do Norte, submetidos à terapia larval. Resultados: os depoimentos dos pacientes/colaboradores apontam diversos valores, como crença, medo, aceitação, melhora da ferida e da dor. Revelaram que não há grande objeção e que o esclarecimento em relação ao tratamento instituído mostrou-se importante na decisão de aceitação. Conclusão: os sentimentos expressos pelos pacientes, como melhora da ferida, diminuição da dor e odor, otimização do processo de cicatrização, surgimento de centelhas de esperança quanto ao retorno à sua vida, dentre outros traduzem os benefícios da Terapia Larval (TL). Apesar do fervilhamento provocado pelo movimento do animal sobre a área acometida e da repulsa que causa a alguns profissionais e pessoas, a TL foi considerada maravilhosa, especialmente por sua eficácia na limpeza da ferida sem a necessidade de novos procedimentos invasivos como desbridamento cortante e cirúrgico.

DESCRITORES: Assistência centrada no paciente; Cicatrização de ferida; Terapia biológica; Estomaterapia.

\section{RESUMEN}

Objetivo: describir la percepción del paciente sometido a terapia larval. Método: estudio cualitativo, exploratorio-descriptivo, teniendo como técnica la de recolección de datos y referencial metodológico la historia oral, en la modalidad de la historia oral de vida. En el estudio participaron seis pacientes con heridas de difícil cicatrización, con seguimiento de la comisión de curaciones de un hospital escuela en Natal, Rio Grande do Norte, sometidos a terapia larval. Resultados: Ios testimonios de los pacientes/colaboradores señalaron diversos valores, como creencias, miedos, aceptación, mejora de la herida y del dolor. Revelaron que no hay gran objeción y que la aclaración con relación al tratamiento instituido se mostró importante en la decisión de aceptación. Conclusión: los sentimientos expresados por los pacientes, como mejora de la herida, disminución del dolor y olor, optimización del proceso de cicatrización, surgimiento de chispas de esperanza en cuanto al retorno a su vida, entre otros traducen los beneficios de la Terapia Larval (TL). A pesar de la convulsión provocada por el movimiento del animal sobre el área afectada y de la repulsión que causa a algunos profesionales y personas, la TL fue considerada maravillosa, especialmente por su eficacia en la limpieza de la herida sin necesidad de nuevos procedimientos invasivos como desbridamiento cortante y quirúrgico.

DESCRIPTORES: Asistencia centrada en el paciente; Cicatrización de herida; Terapia biológica; Estomaterapia.

\section{INTRODUCTION}

Caring for patients with skin wounds, especially chronic wounds, is challenging, complex, comprehensive and requires skill, scientific knowledge, holistic vision and multi-professional work ${ }^{1}$.

For several patients, the wound can have meanings far beyond the physical order, it is often an imperfection, it generates restrictions, such as limitation of movement, difficulties in the development of work activities, leisure and mobility, fears, social isolation, pain and odor that interferes in daily life, resulting in social and emotional imbalances ${ }^{1-3}$.

In this sense, it is necessary to consider, in therapeutic planning, the patient's perception of his wound, difficulties in healing, possibilities of treatment, time to solve the problem and not only the choice of dressing and coverage.

The market has a range of products of different sizes, models and composition for the purpose of maintaining the microclimate, removing debris, protecting granulation tissue, among others ${ }^{4,5}$.
The present study deals with one of the therapeutic possibilities that brings together numerous benefits and prepares the wound bed to receive one of these coverings, which is Larval Therapy (LT), also known as: maggot therapy, larval therapy, biotherapy or bio-surgery $y^{6-9}$. It is a therapeutic, artificial myiasis, induced and controlled by a team of professionals that monitors the entire process, from the capture of the fly in the wild, to the application and removal of the larvae in the injured person ${ }^{7-9}$.

Live larvae of previously decontaminated necrobiontophagous fly species are placed with the intention of promoting healing ${ }^{6-9}$. The larval action goes far beyond biological debridement, through the modulation of the immune response and the release of substances with disinfectant capacity ${ }^{7,10}$. It is a therapy considered safe and widely used in several countries ${ }^{11}$.

The continents that supply and distribute larvae for therapeutic purposes are: Europe (United Kingdom, Germany, Austria, Slovenia, Slovakia, Croatia); Asia (Japan, Iran, Israel, South Korea, Malaysia, Philippines, Singapore and Saudi Arabia); Africa (Egypt); and Oceania (Australia) $)^{12}$. 
Despite being a technique known worldwide by the scientific community and presenting effective results, in Brazil its use is restricted to guinea pigs, except for the work developed at Hospital Universitário Onofre Lopes (HUOL), which in 2012 started the first applications of the larva in humans for the treatment of wounds that are difficult to heal, pioneering the use of the species Chrysomya megacephala (Calliphoridae) $)^{13-15}$.

The treated cases showed an effective response to LT and the advantages identified were: exuberant granulation tissue, release of enzymes with antimicrobial properties, speed in the process of digestion of necrosis, selectivity, speed in tissue repair, easy handling both in the hospitalized patient and at home and ambulatory ${ }^{13,14}$.

\section{OBJECTIVE}

Describe the perception of patients with difficult-toheal wounds undergoing LT.

\section{METHOD}

It is a qualitative, exploratory and descriptive research, using oral history as a method of data collection and methodological framework, in the form of oral life history. According to Meihy16, this modality means a set of life experiences of a person, narrated by them, in which the perception is much more subjective than objective.

Assuming that each person has a history, with its particularities and uniqueness, the oral life history addresses the guiding questions of this study and also justifies the choice of methods, procedures and techniques according to the specificities of the proposed scientific investigation.

The research was carried out at HUOL, located in the city of Natal, state of Rio Grande do Norte, Brazil. Hospital care institution belonging to the Federal University Universidade do Rio Grande do Norte (UFRN). The choice for the aforementioned scenario is due to the fact that it is considered, in Brazil, the first and only one to use LT for the treatment of wounds in human beings ${ }^{13,14}$.

Thus, after authorization by the directorate-general to carry out the research and approval by the Research Ethics Committee of the Liga Norte Riograndense Contra o Câncer (CEP/LIGA), under protocol 108947/2016, they were selected through the patient care records with wound of HUOL the participants called "collaborators" (all patients submitted to LT in the period from 2012 to 2016), making a total of 11 collaborators.

Six collaborators were interviewed. Among the 11 selected, 3 died before the study started, 1 did not accept to participate and 1 had to interrupt the interviews due to worsening health conditions.

When they were invited to participate in the research, they were presented with the proposal, received clarifications about its scientific character, justification, objectives, expected results, as well as the relevance of their contributions.

For data collection, semi-structured interviews with open questions related to the experience of being cared for before becoming sick, living with the difficult-to-heal wound, initial impressions about LT, feelings about the larva in their wound and the changes that occurred after treatment with LT.

The interviews took place in September 2016, privately, on a day, time and place chosen by them, who mostly preferred their own residence as a setting, and because they felt more comfortable, their memories flowed spontaneously. Each collaborator granted 2 interviews with an average duration of 2 hours.

The testimonies were recorded in a digital audio recording and safeguarded the premises required by Resolution 466/2012 of the National Health Council, which provides for research involving human beings, the Free and Informed Consent Term (ICF) and the letter of consent were signed.

At the end of the interviews, the reports were submitted to transcription, which is the process of recreating the speeches of the employees, transforming them into literary reports, which were subsequently checked and approved by them, in accordance with the proposed methodology.

To record the reactions, postures and expressions of the collaborators, a field diary was used, in which the "vital tone" was recorded, which corresponds to a phrase or word that synthesizes the narrative ${ }^{16}$.

In order to guarantee the anonymity of the collaborators, together with them, fictitious names were chosen, represented by songbirds belonging to the Brazilian fauna, by the free association of the text of Santos that deals with the communication of birds ${ }^{17}$.

In the interpretative approach chosen, we tried to describe each experience respecting the way it was experienced, from the collaborator's perspective. 


\section{RESULTS}

In this space, the life history of each collaborator will be presented, including the sociodemographic characteristics and particularities of their life trajectories, which runs through the period before the illness, the treatment with LT until the present day. The narratives revealed "vital tones" that made it possible to understand concrete phenomena from the collaborator's experience.

\section{Characterization of collaborators}

The sociodemographic characteristics of the collaborators included: age between 27 and 72 years old, 5 male and 1 female, of which $84 \%$ had diabetes mellitus with complications resulting from it, especially amputation.In the same proportion is the level of education, in which five have completed high school and incomplete elementary school, of these, four are married and two are single, most of them receive up to one minimum wage from social security. The religion is predominantly Catholic (only one evangelical).

\section{The experience of being cared for before falling ill}

When asked about their life before becoming ill, the answers that emerged refer to the onset of the disease, especially "diabetes" and the advent of the wound. Little was said about being healthy.

Before diabetes I was a guy who lived well, worked day and night and felt nothing, until an injury appeared under my foot, then I started to suffer. (Azulão)

In fact my life was very peaceful, until that simple scratch on the side of my foot appeared, that took time to heal, then a friend asked about my rates, went to the doctor, did the tests and knew I had diabetes. (Galo de Campina)

Before I discovered diabetes, I had a normal life, I did everything, after I found out I started to rule some things, take out of my life, but I continued to insist, I played with diabetes, I played, I played and she ended up with me, she beat me (Fim Fim)

I have lived with the disease since 77 , when I had a venous thrombosis in my leg, so I was hospitalized for almost 30 days and my leg was very swollen, which I had to lose. (Coleirinha)

I was 5 to 6 years old when my mother took me to a hospital and found out that I had type I diabetes. I actually lived with this disease, even today. (Trinca Ferro)

\section{Living with a wound that is difficult to heal}

The presence of the wound was mainly represented by conflicts, fear, anguish, shame, hopelessness and overcoming, in which the history of the wound converges to the life story itself.

Living with the wound is sometimes despair, I look desperate thinking about something, but it is very difficult. (Fim Fim)

The difficulties of having a wound were great, they were great, because it was the whole foot and I had to mobilize it all, but I've came to suffer the most when the treatment was over. I suffered a lot, very much, I thought I would not escape. (Azulão)

Living with the wound, whether or not it is complicated, I am very afraid of hitting, I cannot step on it, I now walk with crutches so as not to put my foot on the floor, because I am afraid, and I cannot wear any shoes. (Galo de Campina)

Living with the wound is terrible, I don't know what it's like to wash myself under the shower, because I can't get wet, I haven't put on a skirt for more than two years, I don't do anything anymore, I stopped doing hydrogymnastics because of those legs of mine, and even walking was difficult, it bothered me, it burned like pepper, dear. Ah! And I feel ashamed, we feel ashamed. (Coleirinha)

For me, living with the wound is like living in a dream, just taking care of it, nothing happens to it. (Trinca Ferro)

\section{Initial impressions of larval therapy}

When asked what were their first impressions about LT, the responses presented reinforce data already described in the literature. In their statements, the desire for improvement and cure was predominant in the acceptance of $\mathrm{LT}^{6}$.

As I wanted to get well, I was asked and I accepted, that was my impression. (Sabiá)

When asked if I wanted to use the larvae, I said: I want to be the pioneer, I want to be the first! You can go for it, if it's for my good then I want. (Fim Fim)

The nurse spoke to me, said it was an experience that was already being in the United States, and my first impression was as follows, if it is to improve my life, I accept it.I accepted and I did well. (Azulão)

My first impression was: oh, that crap on me! To be honest, at first I didn't like it, but we do everything to get well, so I did it, put it in, twice and I don't regret it, I would put it back if necessary. (Coleirinha) 


\section{Feelings about the larva in their wounds}

During the interviews, the feelings reported by employees are common, among them: seething, itching, scratching, tingling and sometimes nothing.

I felt the animals seething, they put them on, I came home and spent the night well, the other day already at night, it was what I felt seething; it was because they were evolving and having an effect. (Sabiá)

I didn't feel anything because the foot was numb, if I tell you that I felt it's a lie, I didn't feel anything. Sometimes there were 200 or so bugs inside my foot, I didn't even know I had. (Fim Fim)

When I was with the larvae in the wound, I felt that little seething, that from the second day on, but it didn't bother me at all, I felt it was good, because it didn't hurt anymore, it was just that delicious swirl. (Azulão)

I felt like that tingling, but I didn't feel pain, I didn't feel anything anymore. (Galo de Campina)

Oh, it didn't bother me, I just felt their walking, but nothing that took my sleep away, I didn't stop taking a shower or sleeping and eating. (Coleirinha)

It only felt itchy when they walked to eat the dead tissue, that's all. (Trinca Ferro)

\section{Changes that occurred after treatment with larval therapy}

In the testimonies, the collaborators praise the improvement in the color of the wound bed, saying that it turned "red". For them, significant changes occurred during the treatment, and factors such as cleaning and pain improvement were reported, which may influence the process of expansion of LT among those with difficult to heal wounds and health professionals, since positive results encourage acceptance of the method.

While I was doing the treatment with the larvae, I got along well, I didn't feel pain anymore, I didn't feel "sucked" or anything, because before the foot looked like it was inside a fire pit, it was burning. The foot unpinned, the larvae ate all that rotten flesh, the wound was very red. (Azulão)

I used larvae twice, from the first time when I took it I saw a difference, it was very dry, very red, everything was cool, but no new larvae were placed because they died, only on Wednesday did they come again, this time they were placed around of 80 larvae, when they took it off my foot on Friday, it was a blessing, I was discharged and went to the commission's clinic. I thought it was wonderful, a fantastic treatment! (Galo de Campina)
It cleaned, right, the larvae cleaned everything and was not aggressive. When they put the larvae and then took it off, after two days everything was red, it took all those dead tissues, ate everything, it was very good, I didn't think it was bad, if it had been bad I would say. (Coleirinha)

I believe that for those who can bear it is worth it, they do the cleaning indeed. (Sabiá)

Synthesis of narratives (vital tone)

\section{Síntese das narrativas (tom vital)}

After a thorough reading of the narrated stories, the "vital tone" corresponding to the phrase or word that will serve as an epigraph for reading the interviews was chosen ${ }^{16}$, that could be grouped and interpreted, intending to understand the collaborators' life stories.

Sabiás vital tone: But I believe that for those who can bear it, it's worth it, they do the cleaning indeed.

When he realized that his wound did not evolve with conventional treatments, he did not hesitate to accept treatment with LT. However, he could not endure the feeling of bubbling that the larva caused. He said in his report that he believes it is a viable alternative, given that the short space of action supported resulted in an improvement in the condition of the wound.

Fim Fim's vital tone: If it is for my good, then I want it!"

To Fim Fim, The LT it was an excellent treatment for being painless, fast and efficient, but the lack of larvae discontinued the program, coinciding with the worsening of the wound and subsequent amputation of the lower limb. Fim Fim stated, however, that he would certainly recommend that treatment to anyone in need.

Azulão's vital tone: During the time I used the larvae I liked it, it was good.

Azulão stressed that he felt a lot of pain before the treatment and that he was very surprised by the speed of the results. However, the discontinuation of LT treatment, due to the lack of larvae, worsened the wound, resulting in the amputation of a foot. He commented, ending the narrative, that he would indicate the treatment, because it really is good.

Galo de Campina's vital tone: I thought it was wonderful, a fantastic treatment! 
Galo de Campina pointed out that the treatment with LT was very important and effective, in just two applications he felt the difference, although he felt very bad when he saw the larvae dead at the end of a session. He emphasized the speed of treatment and commented that he would do it again, in addition to recommending it to others.

Coleirinha's vital tone: And I feel ashamed, we feel ashamed.

Coleirinha reported having undergone numerous treatments before LT, over the years of the presence of the lesion, including the hyperbaric chamber, describing the limitations and the consequent social isolation. She reveals that, initially, she felt disgust when she was informed that the larvae would be placed on her body, but, as she wanted to be cured, she accepted. Despite not being diabetic, she felt no pain during the applications. She did not regret it and guarantees that, currently, she has seen progressive improvement, even managing to walk again.

Trinca Ferro's vital tone: For me, living with the wound is like a dream, just take care of it and nothing happens to it.

Apparently, Trinca Ferro calmly faced the difficulties and limitations imposed by type I diabetes and chronic renal failure (with dialysis treatment), in addition to a kidney transplant and thrombosis in one of the lower limbs. As for the treatment with LT, he asserts that he did not feel pain, only itching and seething that were bearable to the movements of the larva in the lesion bed. He stressed that he was instructed by the nursing team on autonomous care and that he is not walking due to the new injury, this time on the side of the foot.

\section{DISCUSSION}

When referring to treatment with LT, each collaborator expressed, in a different way, their concerns, suspicions, perplexity, satisfaction, among others. This fact is understandable and expected, in view of the influence of beliefs and values that each one carries with them, as an indissoluble part of their life history. However, there are converging aspects in their narratives: the surprisingly rapid improvement in general wound conditions, the impact on quality of life and overcoming limitations.

Different research on the benefits of LT for wound healing and acceptability to therapy has been published and others are being conducted. There have been reports of its benefits since the time of wars. In the 16th century, during the battle of Saint Quentin, Arizona (1509-1590), surgeon Ambroise Paré reported the beneficial effects of larvae. Likewise, during the Napoleonic wars, surgeon Dominique Jean Larrey (1966-1842) observed an improvement in the healing process of wounded soldiers who were parasitized by larvae. In mid-1914-1918, surgeon William S. Baer says he saw "the most beautiful granulation tissue imaginable" when looking at the wounds of two people parasitized by larvae ${ }^{18}$.

A recent study made use of LT in a patient with a difficultto-heal wound at home, guided by telehealth and its result demonstrated efficacy, effectiveness in debridement, decreased costs with hospitalization and surgical procedure and decreased infectious process ${ }^{19}$. Another study showed bactericidal and bacteriostatic action on larval secretions and excretions of the species Cochliomyia macellaria on two important bacteria, Staphylococcus aureus and Pseudomonas aeruginosa ${ }^{7}$. Corroborating Nezakati et al. ${ }^{20}$, conducted a triple blind clinical trial in the city of Shahroud, Iran, also showing important action against aerugin bacteria, Escherichia coli and Staphylococcus aureus, but with little effect on Enterococcus. Masiero et al. 21,22 identified significant activity of the species Chrysomya megacephala and Lucilia cuprina against the biofilm. In the city of Oaxaca, Mexico, larvae were applied to two patients to treat Fournier's gangrene, with the intention of reducing the number of surgical procedures, and the results were promising, since with only one surgical intervention and posterior larval debridement, the disappearance of necrotic tissue, infection control and growth of granulation tissue was evident ${ }^{9}$.

In the Center-West of Brazil, a survey was conducted through a questionnaire that aimed to know the opinion of hospitalized people about LT as a therapeutic option. 105 patients were interviewed and the result showed that the fear of losing their life, as well as knowledge about the treatment and its benefits, were conditions for acceptance of the technique ${ }^{6}$. Low disclosure is a complicating factor for the acceptability of LT in Brazil ${ }^{15}$.

The results found on the benefits of LT corroborate those presented in this study, since the majority reported improvement in quality of life due to pain relief and speed in the evolution of the tissue repair process. The findings broadened the knowledge about LT and its acceptability, revealing that there was no major objection on the part of the patients, and that the desire to improve, the fear of new surgical interventions, the loss of the limb or part of it, the reduced response or absent from conventional treatments 
and clarification about the treatment were preponderant for decision making.

Studies confirm that the interaction between the professional and the patient is a significant factor, since the relationship maintained between both is fundamental for the patient's adherence to the treatment and consequently to the healing process ${ }^{1,3,6}$.

It is worth noting that the nurse, a professional who is directly involved in assisting the person with a wound, has a fundamental role in this process. It is their competence to assess the injured person and prescribe the most appropriate care, in addition to performing, guiding and supervising the nursing team in the execution of the dressing ${ }^{3,4}$.

It is believed that the qualitative approach based on oral history allowed the patients/collaborators of the study to express their life histories, difficulties, perceptions, fears and anxieties about the therapy. The researchers had to listen to such experiences with all the richness of details that the reports brought.

The study's limitation is characterized by the sample of six patients, however its relevance is confirmed by being the only one to deal with the perception of patients undergoing larval therapy in Brazil.

\section{CONCLUSION}

The feelings expressed by patients, such as improvement of the wound, reduction of pain and odor, optimization of the healing process, emergence of sparks of hope regarding the return to their life, among others, translate the benefits of LT.
Despite the seething caused by the animal's movement over the affected area and the disgust it causes to some professionals and people, LT was considered wonderful, especially for its effectiveness in cleaning the wound without the need for new invasive procedures such as cutting and surgical debridement.

It was unanimous that LT led collaborators to chances of keeping the member or part of it, with less limitations to carry out their daily activities, as well as increased belief in wound healing.

One of the major critical nodes was the discontinuity of treatment due to the lack of larvae, which confirmed the need for greater involvement of managers from all walks of life in order to undertake efforts to insert therapy within the scope of the public health system.

It is hoped that the apprehension of these narratives incites discussions, research among health professionals, particularly nurses, about the benefits of the technique, stimulating its insertion as an integrative practice in health units in order to promote a better quality of life for people with difficult to heal wounds.

\section{AUTHOR'S CONTRIBUTION}

Conceptualization: Silva SM, Millions RM and Costa JE; Methodology: Millions RM, Almeida RC and Silva SM; Investigation: Silva SM,; Millions RM and Almeida RC;Writing - First version: Costa JE and Silva SM; Writing - Review \& Editing: Silva SM, Millions RM and Costa JE; Financing Acquisition: Silva SM and Millions RM; Resources: Silva SM and Millions RM; Supervision: Costa JE and Millions RM.

\section{REFERENCES}

1. Ferreira GE, Costa CO, Richter SA, Pichek E, Santos EP, Kaiser DE et al. Concepções multiprofissionais sobre a integralidade no cuidado à pessoa com lesão de pele. Enferm Bras. 2017 Abril/Set; [cited on 2020 sep 07]; 16(5):259-66. Available at: https://www.researchgate.net/publication/328175949

2. Gomes E, Donoso MTV, Alvarenga AW, Gouveia VR. Compreendendo os significados de se conviver com ferida crônica. Rev Enferm Atenção Saúde [Online] 2018 Ago/ Set;7(2):176-88. https://doi.org/10.18554/reas.v7i2.2396

3. Araújo WA, Assis WC, Vilela ABA, Boery RNSO, Rodrigues VP, Rocha RM. Signifi-cados de viver com ferida crônica: estudo de metassíntese. ESTIMA, Braz J Enterostomal Ther 2020;18:e2420. https://doi.org/10.30886/estima.v18.936_PT

4. Silva RM, Fernandes FAV. Competências do Gestor de Feridas: scoping review. Rev Gaúcha Enferm 2019;40:e20180421. https://doi.org/10.1590/1983-1447.2019.20180421

5. Silva ACO, Filho ESR, Sousa GRS, Silva JFS, Silva AL, Araújo CMS. As principais coberturas utilizadas pelo enfermeiro. Revista Uningá. 2017 Jul/Set; [cited on 2020 aug 08]; 53(2):117-23. Available at: http://revista.uninga.br/index. php/uninga/article/view/1426 
6. Franco LC, Franco WC, Barros SBL, Araújo CM, Rezende HHA. Aceitabilidade da te-rapia larval no tratamento de feridas. Revista Recien 2016 Maio/Jul; [cited on 2020 sep 06]; 6(17):13-8. Available at: https://www.recien.com.br/ index.php/Recien/article/download/144/217

7. Masiero FS, Aquino MFK, Nassu MP, Pereira DIB, Leite DS, Thyssen PJ. First record of larval secretions of Cochliomyia macellaria (Fabricius, 1775)(Diptera: Calliphoridae)in-hibiting the growth of Staphylococcus aureus and Pseudomonas aeruginosa. Neotrop En-tomol 2017;46(1):125-9. https://doi. org/10.1007/s13744-016-0444-4

8. Marcondes CB. Terapia larval de lesões de pele causadas por diabetes e outras doenças. Florianópolis: editora UFSC; 2006. p.88.

9. Fonseca-Muñoz A, Sarmiento-Juménez HE, Pérez-Pacheco R, Thyssen PJ, Sherman R. Clinical study of Maggot therapy for Fournier's gangrene. Int Wound J 2020;1-8. https://doi. org/10.1111/iwj.13444

10. Power G, Moore Z, O `Connor T. Measurent of pH, exudate composition and temperature in wound healing: a systematic review. J Wound Care 2017;26(7):381-97. https:// doi.org/10.12968/jowc.2017.26.7.381

11. International Biotherapy Society. Maggot Debridement Therapy (MDT). [cited em 2020 sep 06]. Available at: http:// biotherapysociety.org/maggot-debridement-therapy-mdt/

12. Stadler F. The maggot therapy supply chain: a review of the literature and practice. Med Vet Entomol 2020;34(1):1-9. https://doi.org/10.1111/mve.12397

13. Pinheiro MARQ, Ferraz JB, Junior MAA, Moura AD, Costa MESM, Costa FJMD et al. Use of maggot therapy for treating a diabetic foot ulcer colonized by multidrug resistant bacteria in Brazil. Indian J Med Res 2015;141(3):340-2. https://doi. org/10.4103/0971-5916.156628

14. Ferraz JB, Pinheiro M, Gama RA. Biocirurgia. In: Blank M, Giannini T, organizadores. Úlceras e Feridas: as feridas tem alma. Rio de Janeiro: Di Livros; 2014. p.864.
15. Brambilla PBT. Terapia larval e Divulgação Científica no Brasil: Até quando serão ne-gligenciadas? [trabalho de conclusão de curso]. Natal (RN): Universidade Federal do Rio Grande do Norte; 2018. Available at: https:// monografias.ufrn.br/jspui/bitstream/123456789/7947/5/ TerapiaLarvalDivulgacaoCientifica_Brambilla_2018.pdf

16. Meihy JCSB. Manual de História oral. 5.ed. São Paulo: Loyola; 2005. v 1. $291 \mathrm{p}$. , HOLANDA F. História oral: como fazer, como pensar. 3 edição. São Pau-lo- SP: Contexto, 2015.P 169

17. Santos ASR. A importância da vocalização na identificação das aves. Boletim CEO n.10. São Paulo; p.27-33. 1994. [cited on 2020 sep 07]. Available at: http://www.ceo.org.br/bolet/ bolceo10.pdf

18. Sherman RA. Mechanisms of maggot-induced wound healing: what do we know, and where do we go from here? Evid Based Complement Alternat Med 2014;2014:1-13. https://doi.org/10.1155/2014/592419

19. Armstrong $D G$, Rowe $V L$, D'Huyvetter $K$, Sherman RA. Telehealth-guided home-based maggot debridement therapy for chronic complex wounds: Peri- and postpandemic potential. Int Wound J 2020;17(5):1490-1495. https://doi.org/10.1111/iwj.13425

20. Nezakati E, Hasani MH, Zolfaghari P, Rashidan M, Sohrabi MB. Effects of Lucilia sericata Maggot Therapy in Chronic Wound Treatment: A Randomized Clinical Tri-al. Chronic Wound Care Management and Research 2020;7:11-7. https://doi.org/10.2147/CWCMR.S248149

21. Masiero FS, Silva DG, Luchese M, Estércio T, Pérsio NV, Thyssen PJ. In vitro eval-uation of the association of medicinal larvae (Insecta, Diptera, Calliphoridae) and topical agents conventionally used for the treatment of wounds. Acta Trop 2019;190:68-72. https://doi.org/10.1016/j. actatropica.2018.10.015

22. Masiero FS, Aguiar ESV, Pereira DIB, Thyssen PJ. First Report on the Use of Larvae of Cochliomyia macellaria (Diptera: Calliphoridae) for Wound Treatment in Veterinary Practice. J Med Entomol 2020;57(3):965-8. https://doi.org/10.1093/ jme/tjz238 